\title{
Cómo los autores de Celestina concibieron el personaje de Areúsa
}

\author{
Joseph T. Snow \\ Michigan State University, Emérito
}

\section{RESUMEN}

En este estudio, se ha rastreado el texto completo de la Tragicomedia de Calisto y Melibea para presentar a la "media ramera» Areúsa como un personaje bien caracterizado por los autores. La consideración de las influencias de su pasado determina las motivaciones de sus acciones en el presente textual, y resulta Areúsa ser una mujer independiente que busca adquirir siempre más solvencia y control de cada paso dado en su vida. Su perfil psicológico se ha trazado a partir de sus apariciones y a través de las diferentes relaciones con los personajes con los quedialoga. Hay una Areúsa pública y una privada, con lo que los autores de la obra evitan estereotipos de la prostituta y nos han regalado un retrato de una persona viva, psicológicamente coherente, que acierta en unas acciones y en otras no.

Palabras Clave: Areúsa, Tragicomedia de Calisto y Melibea, retrato psicológico, agencia, independencia, éxitos de sus creadores.

\section{How the authors of Celestina conceived the character of Areúsa}

\section{ABSTRACT}

In this essay, the entire text of the Tragicomedia of Calisto and Melibea has been scrutinized in order to present a complete portrait of Areúsa, an independent prostitute whose constant ambition for greater agency and independence is the backbone of her active life. Her past plays a vital part in her present conduct and belief in herself. Her psychological profile is coherent and the result of careful planning by the authors of the work. The public and private Areúsa are portrayed in her dialogues with each of the characters she must deal with. Her complete portrait escapes being a fall back on previous stereotypes of the prostitute and she emerges a unique and individual human being.

Key words: Areúsa, Tragicomedia de Calisto y Melibea, psychological portrait, agency, independence, success of her creators. 


\section{Prólogo}

La primera cosa que quiero expresar es mi punto de vista particular y personal. Se trata de un nuevo punto de partida en mis casi cincuenta años de leer, enseñar e interpretar la Celestina. La Tragicomedia de Calisto y Melibea es un texto tan denso que un lector puede analizarlo desde diferentes perspectivas. Esa densidad ha generado múltiples interpretaciones y opiniones a lo largo de los siglos. Si retrocedemos a los comienzos del siglo XVI, la obra fue revolucionaria en muchos sentidos. Últimamente he intentando descifrar cómo los autores de esta gran obra consiguieron romper con la tradición literaria de los siglos anteriores en la creación de nuevos personajes cuyas vidas y actitudes estaban en estrecha relación con la vida cotidiana, de manera diversa a los personajes estereotipados de la tradición anterior.

Mi proyecto actual consiste en un análisis de los trece personajes que participan en los diálogos, monólogos y apartes de Celestina. Inicié el proyecto en 2016 en una conferencia magistral en la Universidad Nacional Autónoma de México, cuyo título fue de lo más sencillo: «Dejar hablar el texto». En ella, mostré diferentes ejemplos de una lectura parcial de la obra, que evidenciaban ciertas contradicciones al no tener en cuenta otras partes o elementos del texto, al fundamentarse únicamente en interpretaciones ya asentadas sobre Celestina. Insistí en que había que hacer un escrutinio del texto completo primero, antes de ofrecer cualquier apreciación. En 2017, inicié la serie de escrutinios de los personajes en las Jornadas de Literatura Medieval Española en Buenos Aires con una plenaria titulada: "Todo sobre Lucrecia» (ver Obras Citadas). Pude demostrar que Lucrecia, considerada un personaje secundario, estaba destinada a desempeñar momentos claves en el avance de la trama de Celestina y en el final trágico de la obra.

Hoy ofrezco un análisis de cómo crearon los autores de Celestina el personaje de Areúsa, una ramera independiente y libre, en contraste con la de su prima, la prostituta Elicia, la última 'moza' que todavía vive con Celestina. Areúsa tiene otra prima, Lucrecia, que está de criada y sirve a Melibea, hija de una familia rica y de una clase social más alta. Areúsa, como veremos, siente envidia y desdén hacia Melibea; la razón es que desearía ser libre y no estar al servicio de nadie, como Melibea, aunque la joven dama vive retraída y marginada en una sociedad patriarcal.

Hay catorce personajes que participan en los diálogos, monólogos y apartes de la obra, pero hay uno, Crito en el auto I, que solo dice cuatro palabras y ya no aparece más. Cada uno de los trece personajes restantes ha sido creado con un pasado que ayuda al lector a entender sus acciones y reacciones en el presente. Cada cual posee un complejo psicológico que, bien analizado, puede enriquecer una nueva lectura de la obra. Y Celestina es una de esas obras que, en mi opinión, se entiende mejor con cada 
relectura. ${ }^{1}$ Los lectores avanzamos aprendiendo poco a poco cuáles son las ambiciones de los personajes, tanto las públicas como las privadas. Y nos familiarizamos con los distintos rasgos psicológicos que nuestran las facetas individuales de cada uno. En Celestina no hay un narrador que vaya marcando las secuencias temporales - que no siempre son cronológicas (Snow 2018) - ni tampoco las motivaciones de las acciones de los personajes. Solo existe diálogo en prosa y algunas canciones en verso que hacen evolucionar la trama. Los autores, creando los diálogos y monólogos y planificando el transcurso del tiempo - a veces hay acciones que ocurren "en off ${ }^{2}$ - junto con las secuencias de las acciones, han generado muchas dificultades para su comprensión. Nuestra ambición consistirá en «dejar hablar el texto» sin postulados apriorísticos.

Cada frase dicha es importante porque está sujeta a la interpretación no solo de los interlocutores que escuchan, sino también de los lectores (y, dicho sea de paso, de los que oyen la obra leída por otro en alta voz). Así, si no se tiene en cuenta cada renglón del texto y su correspondencia con otras frases dichas en él, el lector puede quedar con una comprensión parcial e incompleta de la obra. Celestina, para mí, es una obra tan densa que invita a muchas relecturas para poder captar su esencia, su realismo y profundidad, como una creación nueva que abarca los cambios sociales que caracterizan su momento histórico.

\section{Areúsa}

El nombre de Areúsa es mencionado por Celestina en el primero de los veintiún autos como una mujer de belleza conocida y deseada. La alcahueta la presenta como objeto sexual en su intento de persuadir a un recalcitrante Pármeno, el criado menor de Calisto, para que fome parte de una confederación con ella y Sempronio en su intento de medrar a expensas de Calisto. La mención de una supuestamente inalcanzable Areúsa hace que inmediatamente se le represente su imagen inalcanzable al joven criado, todavía virgen, a quien Celestina le promete: «aquí está quien te la dará» (p. 125), estableciendo así su autoridad sobre la muchacha. ${ }^{3}$ Sin

1.- Ximena Gómez Goyzueta dice lo mismo en la p. 70 de su «La configuración de Gerarda»: "Hablar de la configuración de un personaje, a propósito de la vida y la movilidad que le otorga su autor, es trabajo recurrente en la crítica literaria, y no sencillo. Sobre todo, si nos encontramos ante (...) unos personajes no lineales, generadoras de situaciones laberínticas, hecho en apariencia inexplicables, los cuales necesariamente convocan el ejercicio de lectura y relectura cuidadosa para entender, reconstruir y explicar la propuesta artística en turno" (énfasis añadido).

2.- Podemos citar dos ejemplos de acciones que no se han incorporado en el texto, es decir, «en off»: (1) las tres veces que Celestina ha mencionado a Pármeno a Areúsa y (2), la embajada de Elicia a Sosia para que se presente en casa de Areúsa.

3.- Utilizo la edición de D. S. Severin (Madrid: Cátedra, 1987), indicando las páginas. 
embargo, el lector no conocerá a Areúsa hasta el auto VII. Los autores nos dejan a un Pármeno en cuya cabeza irá repitiéndose la imagen de Areúsa, fomentando sus deseos eróticos.

Una segunda mención de Areúsa se da en el auto III. Sempronio pregunta a Celestina cómo persuadirá a Pármeno para formar parte de su confederación, a lo que la astuta alcahueta contesta con gran confianza: «Haréle aver a Areúsa: será de los nuestros» (p. 143). ${ }^{4}$ Los autores presentan a Areúsa como el anzuelo necesario para asegurar la colaboración de Pármeno en el complot contra Calisto. Antes de conocer en persona a Areúsa, Pármeno seguirá sin formar parte de esa confederación (Snow, 2013).

En Celestina, Areúsa comparte diálogos con Celestina, con sus dos primas, Elicia y Lucrecia, con dos criados de Calisto, Pármeno y Sempronio, y con un fanfarrón vanidoso, Centurio, con quien tuvo una relación anterior. Comentaré y observaré de cerca las distintas relaciones con cada uno de estos personajes. Aparecerán así cuáles eran sus ambiciones sociales y las fases sucesivas de su búsqueda para una cierta independencia y solvencia en una sociedad patriarcal en la que mujeres de su baja condición social y moral habían sido marginadas. ${ }^{5}$ Como lectores, nos enterarnos de sus humildes orígenes y sus actividades en el pasado; lo que puede servirnos para entender su comportamiento en el presente, entre los autos VII al XVIII.

\section{La Areúsa pre-textual; y entra Centurio}

Pármeno, al escuchar su nombre en labios de Celestina en el auto I, exclama: Areúsa, ¿hija de Eliso?» (p. 124). Su padre vive y es también muy conocido. La madre de Areúsa era prostituta, como su hija declara a Elicia en el auto XV, utilizando un eufemismo para recordarla al emprender el plan de venganza contra los amantes protagonistas: "Déxame tú. Que si les caygo en el rastro, quándo se veen, y cómo, por dónde, y a qué hora, no me hayas tú por hija de la pastelera vieja, que bien conosciste, si no hago que les amarguen los amores» (énfasis añadido, p. 299). ${ }^{6}$ Areúsa ha heredado de su madre el no demorar la toma de decisiones, que queda confirmado en el auto XV.

4.- Los autores están preparando a los lectores para la primera aparición de Areúsa en el auto VII. Para el cálculo del tiempo real que transcurre en Celestina, ver Snow (2018).

5.- Dirijo la atención de mis lectores al excelente estudio perspicaz de Rachel Scott (2017) en el que analiza la búsqueda de independencia y agencia de Areúsa (pp. 117-133).

6.- «Pastelera» era un eufemismo común para una trabajadora sexual. A pesar de sus orígenes humildes, Areúsa ha conseguido cierta fama local, viviendo mantenida en la casa de un soldado que le llama «Señora». 
Areúsa es una mujer cuya hermosura está en lengua de todos. ${ }^{7}$ En el momento presente, vive en su propia casa, mantenida por un soldado a quien debe su independencia. Si bien, en el auto VII, al entrar por primera vez en el texto el personaje se nos hace saber que vive sola, cuando le comenta a Celestina: «Sabes que se partió ayer aquel mi amigo con su capitán a la guerra» (p. 203). Esta relación con el soldado que acaba de ausentarse el día anterior dejándola sola, subraya su ambición de querer ser una mujer independiente y con solvencia para guiar su propia vida, sin ser esclava de nadie.

Pero el soldado no es la primera relación amorosa que ha mantenido Areúsa. Ella comenta otra que tuvo con Centurio y que ahora, por la razón de pedirle un favor, vuelve a llamarlo. Las relaciones con el rufián revelan a los lectores una aspecto desconocido de Areúsa antes de ser una ramera actuando en su propia casa. Al comienzo del auto XV, al acercarse Elicia a la casa de su prima para contarle el asesinato de Celestina, Centurio está dentro junto con una furiosa Areúsa que intenta echarle a la calle, gritando estas frases que delatan su relación anterior:

Vete de mi casa, rufián, vellaco, mentiroso, burlador, que me traes engañada, bova, con tus ofertas vanas, con tus ronçes y halagos, asme robado quanto tengo. Yo te di, vellaco, sayo y capa, spada y broquel, camisas de dos en dos a las mil maravillas labradas; yo te di armas y cavallo, púsete con señor que no le merescías descalçar. Agora una cosa que te pido que por mi hagas, pónesme mil achaques. (p. 294)

Parece bastante claro que los enseres que regaló a Centurio - es probable que con su enfado exagere un poco- suman una buena cantidad de dinero, adquirido sin duda alguna a través de relaciones sexuales con clientes que pagaban bien, por lo que es muy factible que Centurio fuera en esa época su proxeneta y recibiera dichos dones como pago a sus servicios. Fijémonos en la suave respuesta de Centurio a esta furia de Areúsa: «Hermana mía, mándame tú matar con diez hombres por tu servicio, y no que ande una legua de camino a pie» (p. 294).

Centurio, rechazando hacerle el favor que le pide, el cual requiere andar «una legua de camino a pie», le menciona otra posibilidad: la de matar a un hombre, que le sería menos arduo. No nos sorprenderá pues, que en su ambicioso afán de vengarse de Calisto, Areúsa recurra a este mismo «rufián, vellaco, mentiroso [y] burlador». Volveré posteriormente al

7.- Esta belleza no solo está remarcada en la reacción de Pármeno: «Maravillosa cosa es» (auto I, p. 124), sino más tarde, en lo que le dice Sosia de su fama en toda la ciudad: «Señora, la fama de tu gentileza, de tus gracias y saber, buela tan alto por esta cibdad que no deves tener en mucho ser más conoçida que conoçiente. Porque ninguno habla en loor de hermosas que primero no se acuerde de ti que de quantas son» (p. 309). 
encargo hecho a Centurio para matar a Calisto, que es un grave error por parte de Areúsa.

\section{Areúsa, Calisto y Melibea}

En el texto, Areúsa y su soldado son vecinos de Calisto. Su casa la pueden ver Tristán y Sosia desde una ventana de la casa de su amo, al final del auto XIV. Cuando ven acercarse por la calle a Elicia, dice Sosia: "Y aquella casa donde entra, allí mora una hermosa mujer muy graciosa y fresca, enamorada, medio ramera, pero no se tiene por poco dichoso quien la alcança a tener por amiga sin grande escote, y llámase Areúsa» (p. 293). Tengamos en cuenta esta cercanía de las dos casas y prestemos atención a lo que dice Areúsa de Calisto que le parece ominoso. Ocurre en el auto IX, en el banquete que acontece en casa de Celestina, cuando tanto Areúsa como Elicia explotan con rencor y furia al llamar Sempronio a Melibea "graciosa y gentil» (p. 226).

Esta mención por Sempronio de la "gentil Melibea» hace que Areúsa, la celosa, haga una descripción muy sesgada de Melibea, compitiendo en denigrarla todavía más que Elicia:

Pues no la has tú visto como yo, hermana mía (...). Todo el año se está encerrada con muda de mil suziedades. Por una vez que haya de salir donde pueda ser vista, enviste su cara con hiel y miel, con unas tostadas e higos passados (...). Las riquezas las hazen a éstas hermosas y ser alabadas; que no las gracias de su cuerpo, que assi goze de mí, unas tetas tiene para ser donzella, como si tres vezes oviesse parido; no parescen sino dos grandes calabaças. El vientre no se le he visto, pero juzgando por lo otro, creo que le tiene tan floxo, como vieja de cinquenta años. (pp. 226-228)

Este desprecio de Melibea viene inmediatamente seguido por una muy reveladora declaración de Areúsa: "No sé qué se ha visto Calisto por dexar de amar otras que más ligeramente podría aver y con quien más él holgasse. Sino que el gusto dañado muchas veces juzga por dulce lo amargo» (énfasis añadido, p. 228). Debemos aceptar que Areúsa, que ve entrar y salir de su casa al vecino Calisto con cierta frecuencia, desea conocerle íntimamente.

Elicia se refiere todavía más negativamente a Melibea en el auto XV, después de conocer las muertes de Celestina, Sempronio y Pármeno: "Y de lo que más dolor siento es ver que por esso no dexa aquel vil de poco sentimiento de ver y visitar festejando casa noche a su estiércol de Melibea, y ella muy ufana de ver sangre vertida por su servicio» (énfasis añadido, p. 299). Con estas palabras, Areúsa está en total armonía con Elicia al oír 
nombrar así a Calisto «aquel vil de poco sentimiento», que está en consonancia con su enfado, pues él nunca la ha preferido a ella como amante. Y escuchar a su prima llamar "estiércol» a Melibea tiene también una consonancia perfecta.

Areúsa al mismo tiempo que siente celos de Melibea, porque es ella la escogida de Calisto, también la odia por ser representante de una clase social a la que difícilmente puede aspirar. Su caracterización de celosa también lo reconoce Tristán cuando se refiere a ella, después de darse cuenta de que había sonsacado a Sosia:

Mira Sosia, y acuérdate bien si te quería sacar algún punto del secreto deste camino que agora vamos para con que lo supiesse revolver a Calisto y Pleberio, de embidia del plazer de Melibea. Cata que la embidia es una incurable enfermedad donde asienta (...) siempre goza del mal ajeno. (énfasis añadido, p. 319)

La envidia que siente Areúsa de Melibea contrasta con su deseo para con Calisto. Pero el asesinato de Celestina y la pérdida de los amantes de ella y su prima Elicia - Pármeno y Sempronio- se transforma en un odio hacia Calisto que lleva a Areúsa a concebir un plan para vengarse de los dos amantes degollados, pero en particular contra Calisto. Veremos que no solo muere Pármeno, con quien Areúsa mantenía un intenso romance por poco tiempo, sino que irrumpe contra Calisto su desdén por nunca haberle prestado atención, su vecino, como amante.

\section{El deseo de solvencia e independencia de Areúsa}

Guardemos en nuestra mente la diferencia entre Areúsa y sus dos primas: una de ellas, Elicia, es la última que se prostituye viviendo con una Celestina muy venida a menos; la otra, Lucrecia, está de criada en la casa de Pleberio y Alisa, representantes de la sociedad patriarcal. Areúsa, «marcada ramera» (p. 319), tiene libertad para seleccionar a quien desee ofrecerle sus servicios $y$, aunque en el pasado ha tenido muchos clientes, el de ahora es un soldado que no pertenece al hampa y la mantiene en una casa privada en el mismo barrio donde vive Calisto. Desea ejercer su libre albedrío como mujer independiente. Este deseo es el que le hace exhalar la conocida diatriba contras las señoras ricas al presentarse la criada Lucrecia en casa de Celestina, interrumpiendo las festividades de los cuatro amantes (auto IX).

8.- Parece probable que cualquier atracción que sienta Areúsa por Calisto — junto con la envidia de Melibea - forma parte de su búsqueda de solvencia e independencia porque en su propia mente se ve como igual a Melibea. Ella en otro momento dirá lo que piensa de las clases sociales: «todos somos hijos de Adam y Eva» (p. 229) 
Areúsa se autodefine con algunas palabras que son el preludio de una larga condena hacia aquellas «señoras» ricas que tratan mal a sus sirvientas: «por esto me bivo sobre mí, desde que me sé conocer, que jamás me precié de llamar de otrie sino mía» (énfasis añadido, p. 232). ${ }^{9}$ Areúsa es consciente de los pasos que ha tenido que dar para llegar a donde está. Su evolución psicológica nos presenta a una mujer que ha llegado, por sus propios esfuerzos, a conocerse a sí misma. Hoy es una mujer despierta, ambicionando todavía más. Por otra parte, cree firmemente en la sabiduría popular, que hará lema de su vida: «Ruyn sea quien por ruyn se tiene; las obras hazen linaje, que al fin todos somos hijos de Adam y Eva. Procure de ser cada uno bueno por sí, y no vaya a buscar en la nobleza de sus passados la virtud» (p. 229).

Es en lo que insiste Areúsa al terminar su diatriba contra las señoras ricas, cuando concluye con orgullo, dirigiéndose a Celestina: «Por eso, madre, he querido más vivir en mi pequeña casa esenta y señora, que no en sus ricos palacios sojuzgada y cativa» (énfasis añadido, p. 233). Esta afirmación la realiza en presencia de sus dos primas, estableciendo un contraste con ellas, lo que es otro acierto de los autores de Celestina. ${ }^{10}$ Areúsa está convencida de su propia solvencia y prefiere vivir una vida en la que escoja sus prioridades. En una relectura de Celestina, la vida anterior de Areúsa configura en gran parte las motivaciones del presente textual. Para Areúsa, la nobleza es algo interior y no exterior.

\section{El presente textual: Areúsa en el auto VII}

Al concluir el auto VI, Calisto se despide de Celestina y manda a Pármeno que le acompañe, puesto que ya es de noche. Durante el camino hablan despaciosamente, intentando la alcahueta hacer que Pármeno forme parte de su confederación para vaciar la bolsa de su amo. Pármeno insiste en que una amistad con Sempronio es imposible. Al mismo tiempo quiere saber más sobre el dinero que (supuestamente) le dejó su padre en herencia. Tesoro inventado sobre la marcha por Celestina en el auto I.

9.- Aunque Areúsa y Melibea pertenecen a distintas capas de la estructura social patriarcal, ambas han tenido que confrontar roles represivos de esa sociedad que las mujeres debieron aceptar. En el caso de Melibea, la «bien guardada hija», se rebela contra la noción del casamiento tradicional, cuando dice a Lucrecia en el auto XVI: «No tengo otra lástima sino por el tiempo que perdí de no gozarle, de no conoçerle, después que a mí me sé conocer; no quiero marido, no quiero ensuziar los nudos del matrimonio (...)» (énfasis añadido, p. 304). Estas dos mujeres pasan de un estado a otro mejor, después de conocerse a sí mismas. Son dos casos paralelos en este autoconocimiento a pesar de pertenecer una a la clase alta y la otra a una clase marginal y baja (el hampa).

10.- La llegada de Lucrecia a casa de Celestina en el auto IX, la prima de Areúsa que sirve en la casa señorial de Pleberio, ocasiona este severo juicio, aunque no implica que Lucrecia sufra como las sirvientas de su diatriba. Areúsa debe saber que Alisa no trata así de mal a su prima. 
En ese momento pasan enfrente de la casa de Areúsa, visible, como he comentado antes, desde la ventana de la casa de Calisto. Esta proximidad hace que Pármeno le recuerde a Celestina su promesa, hecha en el auto I, de conseguirle los encantos de Areúsa, hija de Eliso. Celestina le jura que ha hablado con ella en tres ocasiones sobre él. Celestina intuye en ese mismo momento la posibilidad de hacer que Pármeno forme parte de su confederación. Decide entrar en casa de Areúsa silenciosamente para no llamar la atención de sus vecinos. ${ }^{11}$ Manda que Pármeno quede abajo mientras ella sube, sabiendo que Pármeno oirá todo lo que hable arriba con Areúsa sin que ella sospeche nada.

Como es de noche, Areúsa está preparándose para acostarse, medio desnuda. Siente dolores de la madre, por lo que está sufriendo. Pero Celestina le habla de su belleza, le acaricia y declara que no parece sino una muchacha de quince años. Pensemos en cómo se sentirá Pármeno con todas estas palabras de alabanza del cuerpo de la muchacha. Areúsa, que conoce bien las ministraciones medicinales de Celestina, pide un remedio para curarle los dolores de la madre. El alivio que le propone Celestina es la copulación (con un Pármeno escondido todavía más excitado). ${ }^{12}$

Areúsa declara que quiere y debe ser leal a su soldado, aunque entiende, como la ramera que es, por donde va Celestina. Argumenta Celestina en contra de tener Areúsa un único amante; pero la muchacha, queriendo cambiar de tema, pregunta a Celestina el porqué de su venida ese día y a esa hora. Es ese el momento justo para que la alcahueta le recuerde las tres veces que le ha hablado de aceptar a Pármeno como posible amante, porque lo tiene como un hijo y es compañero de Sempronio, amante de su prima, Elicia. Celestina manda entonces que suba Pármeno, su libido enaltecido por la conversación escuchada entre las dos. Areúsa está atónita, creyendo que había venido Celestina sola: «iNo suba (...), que me fino de empacho! Que no le conozco; siempre ove vergüença dél» (p. 206).

Areúsa, asumiendo que su conversación con Celestina era privada, se sorprende al ver a Pármeno. Ansioso, el joven criado le ruega a la vieja alcahueta que le ofrezca a la joven muchacha todo el dinero que su padre le había dejado. Para Celestina, sin embargo, esto no es un asunto comercial. Es el momento de extraerle a Pármeno su solemne promesa de entrar con ella y su nuevo amigo, Sempronio, en la confederación de los tres contra Calisto. Es el momento de su triunfo que ha perfectamentepre-

11.- Como su soldado se ha ido el día anterior, Areúsa debe cuidar de los que vienen a verla. Ella dice a Celestina: "Que tengo a quien dar cuenta, como has oýdo, y si soy sentida, matarme ha. Tengo vezinas embidiosas; luego lo dirán» (p. 205). Se refiere a su soldado, evidentemente, temiendo que podría matarle si sabe de estas entradas y salidas de su casa.

12.- Un segundo remedio posible sería dar a luz, pero no se lo propone, por estar Celestina interesada en un éxito como alcahueta para un lujurioso Pármeno que está oyendo todo, esperando escondido abajo. 
parado. Accede Pármeno, pues el premio de su consentimiento es poder gozar de Areúsa y de sus encantos.

Celestina quiere verlos en la cama y en unos segundos Areúsa está recibiendo gratamente las caricias de su nuevo amante, si bien pide a la vieja que se vaya. La alcahueta no ha perdido todavía las sensaciones del placer sexual y las rememora en sus encías, como cuando comía jóvenes como Pármeno hace años. ${ }^{13}$ Finalmente les deja en paz, al haber cumplido la promesa hecha a Pármeno en el auto I y conseguir la definitiva confederación en contra de Calisto. Pármeno por fin pierde su virginidad y Areúsa, alabando la enérgica manera de hacer el amor de este amante novel, al llegar la mañana (auto VIII) le pide más todavía. Esta visita nocturna tendrá consecuencias para los tres participantes, como veremos.

\section{Areúsa busca compañerismo}

Areúsa no es ya la misma empachada al inicio del auto VIII. Después de una larga noche de hacer el amor una y otra vez, el remedio (copulación) para su dolor de madre todavía no ha funcionado completamente y pide que Pármeno siga, rogándole coquetamente: «hablemos en mi mal» (p. 212). ${ }^{14}$ Pero Pármeno, aunque increíblemente feliz y satisfecho con su virilidad, piensa en Calisto y teme que le pudiera necesitar. Pero antes de partir, invita a Areúsa a un almuerzo ese mismo día en casa de Celestina, junto con Sempronio y Elicia. Acepta esta cita la joven, queriendo seguir ahora con este nuevo amor. No menciona ya a su soldado, ausente por la guerra. Es una Areúsa que, ahora como antes, quiere dirigir sus propios pasos en la vida.

En el mismo auto VIII, una vez poseída Areúsa - patrocinada por Celestina- y la formación de la deseada confederación a tres, los lectores presencian el preludio irónico del futuro asesinato de Celestina. Con estas palabras, Sempronio felicita a Pármeno su unión con Areúsa:

¡O Dios, y cómo me has alegrado! Franco eres; nunca te faltaré. Como te tengo por hombre, como creo que Dios

13.- Celestina retiene una libido activa a pesar de sus sesenta años. Le dice a Areúsa, refiriéndose a jóvenes como Pármeno: «(...) déstos me mandaban a mí comer en mi tiempo los médicos de mi tierra quando tenía mejores dientes (...) que voy me solo porque me hazes dentera con vuestro besar y retoçar, que aún el sabor en las enzías me quedó; no le perdí con las muelas» (p. 208).

14.- Hay dos referencias en el texto al ardor sexual de Pármeno. En el auto I, Celestina le comenta: "Que la boz tienes ronca, las barvas te apuntan; mal sosegadilla deves tener la punta de la barriga» y Pármeno sin pestañear le replica: «iComo cola de alacrán!» (p. 118). Luego, cuando Celestina quiere vender Pármeno a Areúsa, le describe al joven así: «Mas como es un putillo, galillo, barviponiente, entiendo que en tres noches no se le demude la cresta» (p. 208). Y Areúsa pronto sabrá lo que Celestina alaba de Pármeno. 
te ha de hazer bien, todo el enojo de tus passadas hablas tenía se me ha tornado en amor. No dubdo ya tu confederación con nosotros ser la que deve; abraçarte quiero; seamos como hermanos. (énfasis añadido, p. 217)

Con estas palabras se sella la confederación de dos, aunque se habla de una de tres. Los dos enemigos de antes ahora son amigos, hermanos. Es Sempronio quien - en el auto IX - acercándose con su nuevo "hermano» al almuerzo con Celestina y sus amantes, habiendo quitado toda la comida y bebida de la alacena de Calisto, dice a Pármeno sobre Celestina: «Dexándola, verná forçado otra de cuyo trabajo no esperemos parte como de ésta, que de grado o por fuerça nos dará lo que le diere [Calisto]" (énfasis añadido, p. 223). Los dos estarán dispuestos a tener la parte que les correponde de la ganancia de Calisto incluso por la fuerza.

Esta nueva hermandad de Sempronio y Pármeno prepara a los lectores a lo peor. Si se busca la raíz que lleva al asesinato de Celestina, esta está en el hecho de aceptar Areúsa a Pármeno como amante. Es lo que anula la enemistad anterior entre los dos criados de Calisto y hace que Sempronio llame "hermano» a Pármeno, creando una nueva confederación de dos, dentro de la confederación de tres. Así que los autores reservan para Areúsa unas acciones que avanzan la trama de Celestina hacia las tragedias finales.

\section{Areúsa y Celestina}

Analizaré ahora la relación entre estas dos mujeres. El punto de partida aparece en el Auto VII, cuando Areúsa da razones para no tener relaciones sexuales con Pármeno. La reprimenda de la alcahueta no debió agradarle a la ramera:

[P]aresce que ayer nascí según tu encobrimiento; por hazerte a ti honesta me hazes a mí necia y vergonçosa y de poco secreto y sin esperiencia y me amuenguas en mi officio por alçar a ti en el tuyo. (...) Más te alabo yo detrás que tú te stimas delante. (énfasis añadido, p. 208)

Lo que parece claro es que los autores de la obra confrontan aquí a las dos trabajadoras en el mundo de la prostitución —en distintas fases de su carrera- y que cada una tiene sentimientos ambigüos para con la otra.Subrayan dicha ambigüedad mediante las primeras palabras de Areúsa en el auto VII. Al ver a Celestina, se dice a sí misma en voz baja: "(Válala el diablo a esta vieja, con qué viene como huestantigua a tal hora)» (p. 201), que anticipa las tensiones entre las dos. Pero las primeras palabras dichas en voz alta a Celestina revelan una Areúsa que tampoco quiere ofender a 
la alcahueta: «Tía señora. ¿qué buena venida es ésta tan tarde?» (p. 201). Efectivamente, vemos a una Areúsa que controla la situación a pesar de su desconcierto inicial.

Esta ambigüedad entre las dos se enfatiza más en el auto XVII, muy bien diseñado por los autores. Lo que no sabía Areúsa para su plan de venganza contra Calisto y Melibea es en qué noche iban a encontrarse. El lector ya sabe que Sosia conoce a Elicia, el mozo de caballos de Calisto, que conforma con Tristán los nuevos criados que le acompañan al jardín de la casa de Pleberio. Elicia promete a Areúsa que hablará con el joven criado para convencerle de que la bella Areúsa quiere verle. Lo hace, pero "en off». Posteriormente, al llegar Elicia a casa de Areúsa en el auto XVII, ésta le anuncia que está esperando a Sosia para sonsacarle la información tan esencial para su venganza. De repente, llega Sosia. Areúsa coloca a Elicia detrás de una cortina para que pueda ser testigo de sus artes de persuasión..$^{15} \mathrm{La}$ bella ramera tiene un objetivo personal en esta entrevista con Sosia, la de sonsacarle los datos de la cita entre los enamorados, porque cree que Calisto y Melibea son culpables de las muertes, no solo de Celestina, pero también de los criados Pármeno y Sempronio, los amantes de ella y Elicia, al asesinar a la alcahueta. Por tanto, solo desea saber en qué noche tendrá lugar el próximo encuentro de los amantes para seguir con su plan de venganza.

Tan pronto como Sosia revela que el próximo encuentro de los amantes es esa misma noche, Areúsa se despide de él, dejándole creer que será su futuro amante, sucesor de Pármeno. La joven demuestra que es una consumada actriz en esta escena frente a tres públicos: el crédulo Sosia, su prima Elicia y los lectores. Elicia, detrás de la cortina, murmura maravillada: "(O sabia muger, o despediente propio qual le meresce el asno que ha vaziado su secreto tan de ligero)» (p. 312). De nuevo, vemos a una Areúsa completamente con el control, ejerciendo una administración de los hechos eficaz al realizar las cosas a su manera.

Celestina está ya muerta, pero el contraste entre las dos profesionales se deja sentir en estas palabras de Areúsa a Elicia sobre la alcahueta: «Pues prima, aprende, que otra arte es ésta que la de Celestina, aunque ella me tenía por bova porque me quería yo serlo» (énfasis añadido, pp. 312-313). A la luz del único encuentro entre estas dos profesionales en el auto VII, que acabamos de comentar, Areúsa se refiere a él, en donde, al parecer, hizo el papel de «bova» en presencia de la vieja. Areúsa hizo creer a Celestina que fue ella la que le convenció para aceptar a Pármeno como amante. Sin embargo, Pármeno fue bien recibido por ella, aunque parecía en ese momento, para no ofender a Celestina, que hacía el papel de «bova». Así

15.- Los lectores reconocerán este truco, antes hecho por Celestina, cuando deja que Pármeno siga escondido abajo mientras ella seduce verbalmente a Areúsa. Ahora Areúsa sigue el estratagema de Celestina. 
que en los autos VII y XVII, Areúsa da muestras evidentes de sus artes teatrales, primero como «la boba» para Celestina, y luego como futuro amante de Sosia (Snow, 2001). Ni es boba ni será amante de Sosia en el futuro. Como actriz convence a todos.

Areúsa da otras muestras de su independencia. Primero, al enterarse de las muertes de Pármeno y Sempronio en el auto XV, cuando exclama a Elicia: « $¡$ mi Pármeno y mi amor, y quánto dolor me pone su muerte! Pésame del gran amor que con él tan poco tiempo avía puesto» (p. 297). Evidentemente, ella da a conocer que hubo más encuentros con Pármeno diferentes al del auto VII, llegando a enamorarse de él. El soldado con quién había vivido ya no figura en sus planes de futuro. Al aceptar a Pármeno como amante es una nueva muestra de su deseo de más solvencia y libertad. Es la muerte de Pármeno, degollado en la plaza a la madrugada junto con Sempronio, lo que la incita a una venganza contra quienes cree que son los causantes: Calisto y Melibea. ${ }^{16}$ Areúsa es una muchacha activa, por lo que concibe sin demorar un segundo un plan vengativo. Ahí reside el contraste con su prima Elicia, que ni idea tiene de lo que deberían hacer.

La segunda muestra de su independencia y solvencia también aparece en una frase que le dice a Elicia en el auto XVII, que de nuevo subraya el contraste entre Celestina y una más independiente Areúsa: «(...) quiçá por bien fuera para entramas la muerte de Celestina, que yo ya siento la mejoría más que antes» (énfasis añadido, p. 308).

\section{Areúsa como vengadora}

Habiendo sentido una atracción por Calisto, celos y desdén por Melibea al haber sido escogida por el galán, y después de entablar otra relación amorosa con Pármeno e inmediatamente perdido ese nuevo amor - para ella siendo Calisto el responsable- Areúsa quiere vengarse ocasionando la muerte del joven enamorado. No pierde tiempo después de conocer las tres muertes:

Calla, por Dios, hermana, pon silencio a tus quexas; ataja tus lágrimas; limpia tus ojos, torna sobre tu vida, que quando una puerta se cierra, otra suele abrir la fortuna, y este mal, aunque duro, se soldará, y muchas cosas se pueden vengar, que es imposible remediar, y ésta tiene el remedio dudoso y la venganza en la mano. (énfasis añadido, p. 298)

16.- Elicia dice y condena: $\ O$ Calisto y Melibea, causadores de tantas muertes, mal fin ayan vuestros amores (...)» (p. 298). 
En este parlamento aparece una cabal prueba de la suficiencia de Areúsa. Momentos después declarará su remedio: Centurio preparará la venganza contra Calisto. ${ }^{17} \mathrm{El}$ control del futuro está - ella lo cree- en sus manos.

Lo que quería saber Areúsa es en qué momento se van a encontrar los dos jóvenes amantes, lo que consiguió a través de la amistad entre Elicia y Sosia, como vimos. Así conseguirá poner en acción su plan con Centurio. Areúsa achaca a Calisto la responsabilidad de las muertes de Celestina, Pármeno y Sempronio, así como le inculpa de pertenecer a la sociedad patriarcal. Confía en su arte suasorio (lo hemos visto en el caso de Sosia) para convencer a un Centurio - quien le había declarado que preferiría matar a "diez hombres por tu servicio» (p. 294) que caminar una legua a pie-, para que asesinara a Calisto.

Tengo que poner en claro dos cosas. La primera es que Calisto muere, pero no por la intervención de Centurio, como quería Areúsa, por lo que el asesinato como planeaba no se efectuó. La segunda es el error de la ramera en confiar en un Centurio a quien conocía de antaño como «mentiroso, burlador» (p. 294). Es cierto que Centurio miente a Areúsa al aceptar el reto de matar a Calisto, sin embargo, nada más dejarle las dos primas, Centurio dice entre dientes: "Allá yrán estas putas atestadas de razones; agora quiero pensar cómo me excusaré de lo prometido, de manera que piensen que puse diligencia con ánimo de executar lo dicho, y no negligencia (...)» (énfasis añadido, p. 317).

Centurio nunca pensaba cumplir el encargo, por lo que mandó a Traso el cojo y sus compañeros a "dar un repiquete de broquel» (p. 318) fuera del huerto de Pleberio. Irónicamente, el repiquete que crea Traso sí hace que Calisto salga rápidamente - después de hacer el amor tres veces, según Lucrecia - para defender a sus criados, Tristán y Sosia, pero sin volver a armarse -como le implora Melibea-. En su prisa pone un pie mal en la escala, cae y muere descalabrado, sin tener en cuenta lo que Tristán le dice: «Tente, señor, no baxes, que ydos son» (p. 326).

Esta traición de Centurio y su actitud rebelde «encapsula la tensión entre la libertad y las restricciones que Areúsa descubre en su propia lucha por su independencia» (Scott, 131, mi traducción). En su plan de venganza, Areúsa quiere hacer que todo acontezca según sus previsiones, pero no lo logrará. Su deseo era que Calisto muriera por la espada de Centurio, como Celestina con la espada de Sempronio, pero el galán muere por la

17.- El énfasis de Areúsa es siempre Calisto: «Y si pongo en ello a aquel con quien me viste que reñía quando entravas [Centurio] si no sea él peor verdugo para Calisto que Sempronio de Celestina,» pero tampoco se olvida de lo que significará para Melibea su venganza: «le haré armar un lazo con que Melibea llore quanto agora goza» (auto XV, p. 299). Areúsa hasta se jacta de su suficiencia: "Ay prima, prima, cómo sé yo, quando me ensaño, rebolver estas tramas, aunque soy moça. Y de ál me vengue Dios, que de Calisto, Centurio me vengará» (p. 300). 
prisa al bajar la escala de acceso al huerto de Melibea y termina con la cabeza en tres piezas. ${ }^{18}$

Ahora bien, si analizamos las negociaciones entre Areúsa y Centurio en el auto XVIII, encontramos a la muchacha con una inusual ceguera ocasionada por la urgencia de causar la muerte de Calisto esa misma noche. Inicialmente, será Elicia la que haga que entre su prima en la casa de Centurio y éste, aprovechando de esta vacilación, vuelve a jactarse para impresionar a una cauta Areúsa:

Mándame tú, señora, cosa que yo sepa hacer, cosa que sea de mi officio; un desafío con tres juntos, y si más vinieren que no huya por tu amor; matar un hombre, cortar una pierna o braço, (...) estas tales cosas antes serán hechas que encomendadas (...). (p. 314)

Las palabras «matar un hombre» coinciden con lo que Areúsa iba a pedirle, lo que le da la suficiente confianza para responderle: «(...) ya te perdono con condición que me vengues de un cavallero que se llama Calisto, que nos ha enojado a mí y a mi prima» (p. 315). Le pregunta Centurio si está confesado, y la iracunda Areúsa le responde que «no seas cura de su alma», a lo cual responde el rufián: "Pues, sea assí, embiémoslo a comer al infierno sin confessión» (p. 315), palabras que hacen que le perdone por mentiroso.

La necesidad y la urgencia de vengar las muertes del amante suyo y el de Elicia prima sobre la historia pasada entre ella y Centurio. Areúsa, sin saberlo, se ha equivocado. La ironía es que, delante de esta gran actriz, la teatralidad de la exposición de Centurio le vence. Él — como ella - también es un actor convincente. Nunca sabremos la reacción de Areúsa a la historia verdadera de la muerte accidental de Calisto porque, después de este auto XVIII, Areúsa no tiene más presencia en la obra.

\section{La Areúsa pos-textual}

Esta conversación con Elicia y Centurio será la última aparición de Areúsa como personaje en Celestina. Con el éxito que piensa conseguir mediante la promesa de Centurio de matar a Calisto, cree que ha llegado a la cima de su deseo para ejercer el dominio y control de los eventos en su vida. Está convencida de ello. Pero no tendremos como lectores

18.- Irónicamente, los autores anuncian sutilmente este fin de Calisto en el auto I, cuando el joven enamorado manda a Sempronio que solicite ayuda a Celestina y ésta reacciona con alegría por la posibilidad de remuneración de la embajada propuesta: «Digo que me alegro de estas nuevas, como los cirujanos de los descalabrados (...)» (énfasis añadido, p. 107). Y poco después del suicidio de Melibea, Pleberio está contemplando a la forma inerte de su hija «hecha pedazos» (p. 336). 
otra oportunidad de conocer cómo reaccionaría al saber la realidad de la muerte de Calisto y el error que ha cometido en su plan de venganza contra el amante de Melibea. Y, dicho sea de paso, Traso y sus compañeros no tenían ningún mandato para matar a Calisto. ${ }^{19}$ La traición de Centurio no sorprende al lector que sabe cómo es.

Quedan todavía en Celestina los autos XIX, XX, y XXI. Al concluir nuestra lectura de Celestina, los cinco protagonistas han fallecido. Asesinada (Celestina); degollados por orden de un juez (Sempronio y Pármeno); muerto en una caída absurda (Calisto); o suicidándose (Melibea) dejándose caer de la torre. Con la muerte de su única hija delante de sus ojos, el mundo de Pleberio se desmorona y el texto acaba en una avalancha de pesimismo.

Lo que podría suceder en el futuro a los personajes, que permanecen vivos al final de la obra, es cuestión de conjeturas y quiero exponer unas pocas mías. Calisto muerto, Tristán y Sosia tendrán que servir a otro amo. Lucrecia ya no puede seguir empleada en la casa de Pleberio una vez muerta Melibea, y es probable que - como sus dos primas- termine siendo prostituta. Muerta Celestina, Elicia - que inicialmente no quería abandonar la casa de Celestina por tener el alquiler pagado y por ser el lugar donde la conocen - descubre que ya nadie le visita —es más que probable que aceptará la oferta de Areúsa para irse a vivir con ella o juntas en casa de Celestina.

Pensando ahora en el futuro de Areúsa, creo que hay otras posibilidades más interesantes. En el futuro -y en parte relacionado por la seducción de Sosia- puede seguir ejerciendo de ramera en el caso de que el soldado, cuando vuelva de la guerra, quiera seguir como antes - sin tener conocimiento de sus pasados engaños con los criados de Calisto. Otra solución sería la de no quedarse en la casa que compartía con el soldado, cerca de la de Calisto, e ir a ejercer su profesión con Elicia - y posiblemente Lucrecia- en casa de Celestina. Con el transcurso de los años, podría llegar a ser una alcahueta sabia como Celestina, con un burdel en el que habría muchas chicas - repitiendo la edad de oro como la que tuvo Celestina hace unos veinte años.

Lo que me parece más seguro en el caso de Areúsa es que la lucha por su solvencia e independencia ha encontrado un obstáculo insuperable. A pesar del orgullo que sintió al declararse libre de servir a las ricas señoras

19.- Otra posible explicación de la caída de Calisto de la escala podría no tener relación con su prisa para ayudar a sus criados, sino también con su cansancio. Recordemos — según Lucrecia-que Calisto y Melibea han copulado tres veces ("Ya me duele a mí la cabeza descuchar y no a ellos de hablar ni los braços de retoçar ni las bocas de besar; andar, ya callan; a tres me parece que va la vencida)» (p. 324). Calisto, cansado, solo se detiene para pedir a Melibea su capa, en la que ella estaba reclinada, ignorando su ruego: "O triste de mi ventura, no vayas allá sin tus coraças; tórnate a armar» (p. 326). No lo hace y en su prisa (¿combinado con el cansancio?), pone mal el pie en la escala y cae abriéndose la cabeza. 
que tratan mal a sus criadas, a pesar de su plan de venganza que creía controlar hasta el último detalle, y a pesar de vivir en su propia casa y decidir a quién ofrece sus encantos, el fracaso de su plan muestra que, en la sociedad patriarcal, seguirá marginada. Areúsa tendrá que volver a evaluar sus opciones futuras.

Yo postulo que Areúsa tendría unos 24 o 25 años. Está orgullosa de su evolución: ha pasado de ser la hija de una pastelera a una ramera independiente que no ha finalizado en un burdel sino en su propia casa, bien mantenida por un reconocido miembro de la clase patriarcal, a pesar de que - en el pasado - tuvo sus ganancias al servicio de un rufián (Centurio). Conocía bien a Celestina, una alcahueta muy venida a menos que sigue metida en muchos oficios y con una labia con la que domina a los miembros del hampa. Nuestra Areúsa, a lo largo de sus años, ha adquirido independencia y madurez. Se jacta de conocerse a sí misma y ha aprendido a negociar con los demás en sus propios términos y, como hemos comentado arriba, esto incluye a Celestina.

La lucha por obtener una autonomía completa en una estructura social que marginaba las profesiones sexuales de todo tipo no ha sido nunca fácil para Areúsa. En el texto, la joven ramera ha tenido emociones contrapuestas con Calisto y Melibea: deseo y odio, respectivamente. Ellos son miembros de la alta sociedad patriarcal y su enfado con Calisto por su predilección por Melibea, nos deja vislumbrar que, por debajo de su orgullo y su constante búsqueda de solvencia e independencia, se escondía una mujer celosa y vengativa. Esas emociones conflictivas le han dejado sin poder realizar sus ambiciones sociales.

\section{La Areúsa de los autores de Celestina}

La obra comienza con una muy conocida Areúsa ausente, prometida por Celestina al joven Pármeno, todavía virgen, como premio a su confederación con ella y Sempronio para poder medrar económicamente del enamorado Calisto. Pero la Areúsa que hemos estado analizando aparece físicamente en la segunda mitad del auto VII, en la primera escena del auto VIII, y los autos IX, XV, XVII y XVIII. Se ha caracterizado ella misma como hija de una prostituta ("pastelera») que, al madurar, no quiere ser sirvienta de las ricas señoras: busca su independencia después de haber estado al servicio en épocas pasadas del rufián Centurio, consiguiendo cautivar a un soldado que le permite vivir en su propia casa y ejercer su libre albedrío. Pero ambiciona más solvencia e independencia en su vida y entorno.

Hemos visto, también, a una Areúsa que sabe - como buena actrizdominar con su labia a otros personajes (Sosia, Elicia). Adquiere, con la muerte de Celestina, aún más confianza en sus propias decisiones. Está resentida de la clase privilegiada (Calisto, Melibea) y piensa que es capaz 
de persuadir a Centurio para llevar a cabo su plan de venganza sobre eljoven galán Calisto, miembro de la clase patriarcal y culpable, según ella, de las muertes de Celestina, Sempronio y, especialmente, de Pármeno.

Sin sospecharlo, su tórrido romance con Pármeno será un factor crucial en el asesinato de Celestina (cuando Sempronio le perdona y le llama hermano). Los lectores son testigos de su triunfal conquista del crédulo Sosia (auto XVII). La acción más significativa que los autores les asignan en la obra es el plan de venganza del auto XVIII, cuando permiten que la autoridad y solvencia de Areúsa se socave por otro emotivo actor, Centurio, en su papel de gran matador de hombres.

Areúsa, desesperadamente necesitada de un asesino para esta misma noche, abandona todo su conocimiento de Centurio y comete el único error garrafal en la obra. Desaparece inmediatamente después del texto; los autores solo nos dejan imaginar su reacción y su desilusión al saber de la traición de Centurio y de la muerte accidental de Calisto, con lo que su plan de venganza no tuvo éxito. Pero con el tiempo podría recuperarse de su error. Está claro, sin embargo, como ha observado Rachel Scott en su evaluación de Areúsa, que «la lucha por su autonomía facilita la continuidad de la misma vida social» (p. 133, mi traducción).

En suma, los autores de Celestina nos han dado un retrato memorable de un miembro de una casta marginal, la del hampa, cuyo centro es Celestina, pero que mediante sus actuaciones ha conseguido más solvencia e independencia que sus dos primas, aunque dejan que en la urgencia del momento - es esa misma noche que Calisto va a ver a Melibea-acepte a Centurio y su espada como ejecutores de su plan de venganza y la muerte de Calisto. Esta urgencia le lleva a equivocarse, al desviarse de su acostumbrada sensatez. Al sacar a Sosia la fecha del próximo encuentro entre los amantes protagonistas, actúa con una prisa que no había contemplado. Pero los autores de la obra no se interesan por Areúsa después de sus palabras finales. Al declarar Centurio que va a matar a Calisto por el amor de Areúsa, la joven ramera le deja diciendo: «Pues Dios te dé buena manderecha y a él le encomiendo, que nos vamos» (p. 317).

Los autores no permiten que veamos a una Areúsa derrotada o desilusionada. Sospechamos, sin embargo, que posee ya suficientes habilidades y talentos para poder superar cualquier desilusión, y habrá aprendido a no actuar en el futuro con premeditación. Esta Areúsa, bien caracterizada, enteramente humana y ambiciosa, que puede amar y odiar, que siente compasión por su prima Elicia al morir Celestina, que siente envidia de Melibea por su romance con Calisto, y que adivina cómo quiere Celestina que ella se comporte con Pármeno, resulta ser un personaje diseñando con una psicología reactiva y siempre plausible que se merece - como buenos lectores- nuestra admiración. Está lejos Areúsa de ser una prostituta estereotipada, al ser un personaje de nueva factura creado por los autores de Celestina y muy difícilmente imitable en obras posteriores. 


\section{Obras citadas}

GÓMEZ GOYZUELA, Ximena, (2017). «La configuración de Gerarda: Pre-texto y sub-texto en La Dorotea de Lope», Signos literarios 13, 25, pp. 68-99.

SCOTT, Rachel (2017). 'Celestina' and the Human Condition in Early Modern Spain and Italy. Woodbridge, U. K., Boydell and Brewer (Tamesis).

SEVERIN, Dorothy S., ed. (1987). Fernando de Rojas, La Celestina, Letras hispánicas 4, Madrid, Cátedra.

SNOW Joseph T. (2001). "The Staging of Impromptu Theatricals in Celestina: Three Cases». In Tras los pasos de "La Celestina", ed. P. Botta, F. Cantalapiedra, K. Reichenberger \& J. T. Snow, Kassel, Reichenberger, pp. 297-314.

SNOW, Joseph T. (2013). «Confederación e ironía: crónica de una muerte anunciada (Celestina, autos i-xii)», Celestinesca 37, pp. 119-138.

SNOW, Joseph T. (2018). "La cuestión peliaguda del tiempo en Celestina: propuesta de acotaciones escénicas", Celestinesca 42, pp. 269-290. 
